\title{
The Role of Calcium Ions to Improve Activity of Chitinase Isolated from Vibrio sp.
}

\author{
Noor Harini ${ }^{1}$, Ya Xi Han², and Johan Sukweenadhi $i^{3, *}$ \\ ${ }^{1}$ Department of Food Science and Technology, Faculty of Agriculture-Animal Science, University of Muhammadiyah Malang, \\ Jl. Raya Tlogomas No 246, Malang 65114, Indonesia; ${ }^{2}$ Graduate School of Biotechnology, College of Life Science, Kyung Hee University, \\ Yongin-si, Gyeonggi-do, 17104, Republic of Korea; ${ }^{3}$ Department of Bionutrition and Food Innovation, Faculty of Biotechnology, \\ University of Surabaya, Jl. Ngagel Jaya Selatan No 169, Surabaya 60294, Indonesia.
}

Received: May 15, 2021; Revised: June 18, 2021; Accepted: June22, 2021

\begin{abstract}
Chitinase (EC 3.2.1.14) plays a crucial role in chitin degradation, specifically breaking down the $1 \rightarrow 4 \beta$-glycosidic bonds of $\mathrm{N}$-acetyl-D-glucosamine (GlcNAc) to produce its mono- or oligomers. This study aims to study the characteristics of chitinase from Vibrio sp. (isolated from tiger shrimp in Indonesia) and explore the role of calcium ions $\left(\mathrm{Ca}^{2+}\right)$ in increasing chitinase activity. The optimum condition for chitinase activities is $\mathrm{pH} 7.5,45^{\circ} \mathrm{C}$ of temperature, and $120 \mathrm{~min}$ of incubation time. The enzyme activity parameters such as $\mathrm{K}_{\mathrm{m}}$ and $\mathrm{V}_{\max }$ values were calculated by varying the concentration of $\mathrm{Ca}^{2+}$, namely: $0 \%$; $0.2 \% ; 0.4 \% ; 0.6 \% ; 0.8 \%$. The final product of the chitinase reaction, the GlcNAc, is then used to measure the enzyme activity based on the Somogyi-Nelson method. The results showed that chitinase isolated from Vibrio sp. has increasing activity with the addition of $\mathrm{Ca}^{2+}$. Without the addition of $\mathrm{Ca}^{2+}$, the $\mathrm{K}_{\mathrm{m}}$ and $\mathrm{V}_{\max }$ of chitinase were $7.781 \mu \mathrm{mol} \mathrm{mL} \mathrm{m}^{-1}$ and $0.066 \mu \mathrm{mol} \mathrm{min}^{-1}$, respectively. The treatment of $0.4 \% \mathrm{Ca}^{2+}$ shows optimum activity with the $\mathrm{K}_{\mathrm{m}}$ and $\mathrm{V}_{\max }$ at $6.723 \mu \mathrm{mol}$ $\mathrm{mL}^{-1}$ and $0.079 \mu \mathrm{mol} \mathrm{min}{ }^{-1}$, respectively. The results showed the potential use of $\mathrm{Ca}^{2+}$ as a chitinase activator to fulfill demands for energy-efficient and economically profitable chitinase usage.
\end{abstract}

Keywords: Eco-friendly waste management, Enzyme activity, Marine waste, Profitable chitinase, Utilization of Agro-industrial waste.

\section{Introduction}

Chitinase is an enzyme that catalyzes the hydrolysis reaction of $\mathrm{N}$-acetyl-D-glucosamine (GlcNAc) polymers. It can be used in the decomposition and re-utilization of chitin, one of the major marine waste problems (Atalla et al., 2020). GlcNAc itself has been widely applied in the health sector, including reducing blood pressure and blood fat levels, suppressing cancer cell development, malignant tumors, and other inflammation, low-calorie sweeteners, cosmetics, biocontrol agents, and packaging materials (Awad et al., 2014; Krolicka et al., 2018; Rathore and Gupta, 2015; Van den Broek et al., 2015; Veliz et al., 2017). Thus, looking for the chitinase can be key to reducing environmental hazards through eco-friendly waste management and generating an added-value product that is important to the industry (Hamed et al., 2015; Jahromi and Barzkar, 2018; Sadik et al., 2021).

Chitinase is a chitinolytic enzyme in cell organisms and can be synthesized from various sources such as bacteria, fungi, and various other types of microorganisms. Chitinase synthesized by animals and plants has several functions, including helping the metabolic process and preventing infections, such as preventing the growth of fungi or bacteria that can damage the individual's tissues. Chitinase, which is produced by bacteria, has the function to degrade chitin into compounds that can fulfill the nutritional needs of these bacteria (Adrangi and Faramarzi, 2013). Recent chitinase isolated from several species of Vibrio $s p$. has optimum enzyme activity at $\mathrm{pH} 5$ to $\mathrm{pH} 7$ with incubation temperature at $45{ }^{\circ} \mathrm{C}$ to $50{ }^{\circ} \mathrm{C}$ (He et al., 2020).

Vibrio sp. is a bacterium often found in prawns bred in brackish water or from the water itself (Felix et al., 2011; Kharisma and Manan, 2012; Kusmarwati et al., 2017). It can infect and cause diseases, namely Vibriosis, which can cause huge loss in shrimp culture. This disease is caused by bacteria Vibrio genera such as $V$. harveyi, $V$. alginolyticus, $V$. parahaemolyticus, and $V$. penaeicida (Utami, 2016). Some cofactors such as $\mathrm{Na}^{+}, \mathrm{Ca}^{2+}, \mathrm{Mn}^{2+}, \mathrm{Fe}^{2+}, \mathrm{Fe}^{3+}, \mathrm{Cu}^{2+}$ and $\mathrm{Zn}^{2+}$ can function as chitinase activators (Jahromi and Barzkar, 2018). The presence of calcium ions in brackish

\footnotetext{
* Corresponding author e-mail: sukwee@staff.ubaya.ac.id.
} 
water is normal due to efforts to regulate salinity conditions, which later relate to the Vibrio survivability, osmoregulation, and post-larval metabolic ability of shrimp (Taqwa et al., 2014). Based on these problems, it is necessary to examine the effect of $\mathrm{Ca}^{2+}$ in addition to increasing chitinase activity. After finding the chitinase optimum parameter, chitinase activity with and without the addition of $\mathrm{Ca}^{2+}$ will be compared. This can be known by measuring $\mathrm{K}_{\mathrm{m}}$ (Michaelis-Menten coefficient) and $\mathrm{V}_{\text {max }}$ (maximum $\mathrm{V}$ value). The study aims to determine the role of $\mathrm{Ca}^{2+}$ ions in increasing isolated chitinase activity from Vibrio sp.

\section{Materials and Method}

\subsection{Research materials}

The research was conducted in the Laboratory of Parasites and Fish Diseases, Department of Aquaculture, Faculty of Fisheries; Biochemistry Laboratory, Biomolecular Laboratory, Microbiology Laboratory, Faculty of Mathematics and Natural Sciences, Brawijaya University, Malang; Agricultural Product Technology Laboratory, Agricultural Biotechnology Center, Science and Technology of Food Laboratory, University of Muhammadiyah Malang; and Bionutrition and Food Innovation Laboratory, Faculty of Biotechnology, University of Surabaya. The materials and tools used include a tool to characterize chitinase and test the enzyme activity. The Vibrio sp. used in this research was obtained from previous work (Zafran et al., 2017) located at Provincial Fish Seed Center (Balai Benih Ikan ProvinsiBBIP), Gondol, Bali. The strain was isolated from tiger shrimp (Penaues monodon Fabricius, 1798), and the only one which is non-pathogenic was used in this research.

\subsection{Preparation of Vibrio culture}

The solid medium was made for the propagation of Vibrio bacteria in a petri dish (Pyrex 3160-100), wherein how to make it followed previous work by Zarkasi et al. (2019) with some modification. Nutrient composition so that TCBSA (Thiosulfate-citrate-bile salts-sucrose agar, Oxoid, United Kingdom) for $1 \mathrm{~L}$ was needed as much as 88 $\mathrm{g}$ so that for making solid medium as much as $20 \mathrm{~mL}$ it was needed TCBSA as much as $1.76 \mathrm{~g}$ and chitin (Oxoid, United Kingdom) as much as 0.4 g. Nutrients to be dissolved in distilled water to a volume of $20 \mathrm{~mL}$, heated to boiling for $10 \mathrm{~min}$ then put $10 \mathrm{~mL}$ each into petri dish that has been sterilized in an autoclave (All-American 25×, USA) at $121{ }^{\circ} \mathrm{C}$, pressure $1.5 \mathrm{~atm}$ for $15 \mathrm{~min}(1 \mathrm{~atm}=101$ $325 \mathrm{~Pa}$ ). Furthermore, it was desirable for cooling it down at room temperature $\left(25^{\circ} \mathrm{C}\right)$ to harden. In another way, a liquid medium was used for Vibrio growth medium on growth curves and enzyme production. The medium used for making liquid medium was TSB (Tryptone Soya Broth, Oxoid, United Kingdom). To make $100 \mathrm{~mL}$ of liquid TSB medium, 3 g TSB, 0.5 g NaCl (Oxoid, United Kingdom), and $2 \mathrm{~g}$ chitin were dissolved in $100 \mathrm{~mL}$ distilled water and then sterilized in an autoclave at $121{ }^{\circ} \mathrm{C}, 1.5 \mathrm{~atm}$ for 15 $\min$.

\subsection{Isolation of crude chitinase}

Vibrio sp. cultures that had been rejuvenated for $2 \mathrm{~d}$ (day) were taken using a loop wire and suspended in $20 \mathrm{~mL}$ of the sterile liquid medium in $125 \mathrm{~mL}$ Erlenmeyer flask (Pyrex 4450-125) and placed in a shaking incubator at room temperature $\left(25^{\circ} \mathrm{C}\right)$ for $16 \mathrm{~h}$ (half logarithmic phase). The $20 \mathrm{~mL}$ inoculum solution was inoculated into $200 \mathrm{~mL}$ of sterile liquid medium and grown at room temperature $\left(25{ }^{\circ} \mathrm{C}\right)$ on a shaking incubator (Bionics, BST/MIS-100B, India $)$ at speeds of $125 \mathrm{rpm}(1 \mathrm{rpm}=1 / 60 \mathrm{~Hz})$ to $32 \mathrm{~h}$ (stationary phase). Then it was centrifuged at $4{ }^{\circ} \mathrm{C}$ for 10 min at $3000 \mathrm{rpm}$ (Denley BR401, United Kingdom) and the supernatant was immediately tested for its enzyme activity. The enzyme was purified by the saturated ammonium sulfate (Oxoid, United Kingdom) precipitation method followed by dialysis and Sephadex 75G (Oxoid, United Kingdom) column chromatography method. Each enzyme fractionation was tested for chitinase activity (Harini and Indranila, 2006).

\subsection{Chitinase Activity Test}

The chitinase activity was tested by using SomogyiNelson assay. As much as $1 \mathrm{~mL}$ of $30 \mathrm{mg} \mathrm{L}^{-1} \mathrm{~N}$-acetyl-Dglucosamine (Sigma-Aldrich, Germany) standard solution was taken and added with $1 \mathrm{~mL}$ of the Somogyi-Nelson cooper reagent (Sigma-Aldrich, Germany). The mouth of the tube was covered with aluminum foil, then heated in boiling water for $10 \mathrm{~min}$. The tube was cooled in ice water and added with $1 \mathrm{~mL}$ of arsenomolybdate reagent, shaken, and allowed to stand for several minutes until the foam disappeared. After that, the distilled water was added up to $10 \mathrm{~mL}$ in volume and then shaken and measured the absorbance in the wavelength range of $500 \mathrm{~nm}$ to $800 \mathrm{~nm}$ by UV-vis spectrophotometer (Shimadzu-1601A, Japan), which maximum wavelength $\left(\lambda_{\max }\right)$ was $750 \mathrm{~nm}$ (Shalaby et al., 2019). The arsenomolybdate reagent was made of 25 $\mathrm{g}$ of ammonium molybdate (Sigma-Aldrich, Germany) dissolved in $450 \mathrm{~mL}$ distilled water, $21 \mathrm{~mL}$ of concentrated $\mathrm{H}_{2} \mathrm{SO}_{4}$ (JT Baker, United States), and $3 \mathrm{~g}$ of $\mathrm{Na}_{2} \mathrm{HAsO}_{4} .7 \mathrm{H}_{2} \mathrm{O}$ (Sigma-Aldrich, Germany) dissolved in $25 \mathrm{~mL}$ of $\mathrm{H}_{2} \mathrm{O}$, mix then place in an incubator (Heraeus B5042, Germany) at $37{ }^{\circ} \mathrm{C}$ for $24 \mathrm{~h}$ to $48 \mathrm{~h}$. The standard $\mathrm{N}$-acetyl-glucosamine curves were prepared by testing several $\mathrm{N}$-acetyl-glucosamine concentrations $[10,20,30$, 40, 50, and 60) $\mathrm{mg} \mathrm{L}^{-1}$ ] following exactly Somogyi-Nelson assay which written above.

A total of $1 \mathrm{~mL}$ of $2.5 \%(\mathrm{w} / \mathrm{v})$ chitin in $0.1 \mathrm{M}$ phosphate buffer $\mathrm{pH} 7.5$ was added to $1 \mathrm{~mL}$ of chitinase solution. Then the mixture was incubated at $45^{\circ} \mathrm{C}$ and after $120 \mathrm{~min}$ of incubation time, it was centrifuged at $5000 \mathrm{rpm}$ for $10 \mathrm{~min}$. The enzyme activity was stopped by heating it in boiling water for 15 min before it was mixed with the reagent. Furthermore, the supernatant obtained was taken 
as much as $1 \mathrm{~mL}$ to be tested by Somogyi-Nelson assay. The solution was diluted with distilled water to a final volume of $10 \mathrm{~mL}$ and read the absorbance at $\lambda_{\max }$ with a phosphate buffer blank which was treated the same as the sample. Enzyme activity value was measured by the levels of $\mathrm{N}$-acetyl-D-glucosamine obtained from the plot results against the standard curve of $\mathrm{N}$-acetyl-D-glucosamine. The measurement of enzyme activity was done by converting the absorbance value to the concentration of N-acetyl-DGlucosamine (Yang et al., 2016) and calculating it following equation (1):

Enzyme Activity $=\frac{[N-\text { Acetyl }-D-\text { Glucosamine }] \times V}{M r N-\text { Acetyl }-D-\text { Glucosamine }} \times \frac{d f}{E \times t}$

Note: $\mathrm{V}=$ total sample volume $(\mathrm{mL}), \mathrm{E}=$ amount of crude enzyme $(\mathrm{mL}), \mathrm{t}=$ incubation time $(\mathrm{min}), \mathrm{df}=$ dilution factor, Enzyme Activity (unit) $=\mu \mathrm{mol} \mathrm{N}$-acetyl-D-glucosamine which is produced by each $\mathrm{mL}$ of the enzyme each one minute under certain conditions. The $\mathrm{N}$-acetyl-D-glucosamine obtained was measured absorbance by the UV-Vis spectrophotometer at $\lambda_{\max } 750 \mathrm{~nm}$.

\subsection{Determination of the optimum $\mathrm{pH}$, temperature and} incubation time

The determination of the optimum $\mathrm{pH}$ of chitinase was carried out with a variation of $\mathrm{pH} 6 ; \mathrm{pH} 6.5 ; \mathrm{pH} 7.0 ; \mathrm{pH}$ 7.5; $\mathrm{pH} 8$; and $\mathrm{pH}$ 8.5. Each test tube was provided with 1 $\mathrm{mL}$ chitin $2 \%(\mathrm{w} / \mathrm{v})$ in a phosphate buffer with variation of $\mathrm{pH}$ 6; $\mathrm{pH}$ 6.5; $\mathrm{pH} 7.0$; $\mathrm{pH} 7.5 ; \mathrm{pH} 8$; and $\mathrm{pH}$ 8.5. Then 0.5 $\mathrm{mL}$ of enzyme filtrate was added and incubated at $45^{\circ} \mathrm{C}$ for $60 \mathrm{~min}$. The solution was centrifuged at $5000 \mathrm{rpm}$ for 10 min, then the filtrate obtained was taken $1 \mathrm{~mL}$ and added 1 $\mathrm{mL}$ of Somogyi-Nelson reagents and shaken. The mouth of the tube was covered with aluminum foil and heated for 20 min in boiling water. After chilling, $2 \mathrm{~mL}$ of arsenomolybdate reagent was added, mixed, and allowed to stand for 4 min. Subsequently, the solution was diluted with distilled water to a volume of $10 \mathrm{~mL}$ and the absorption was read at the $\lambda_{\max }$. Then the activity was determined, where the optimum $\mathrm{pH}$ was determined from the graph of the relationship between changes in $\mathrm{pH}$ of the enzyme activity.

Determination of the optimum temperature was done by the same procedure as the method used to determine the optimum $\mathrm{pH}$, while the incubation temperature was varied at $(30,35,40,45,50,55){ }^{\circ} \mathrm{C}$ for $60 \mathrm{~min}$ at $\mathrm{pH}$ 7. Then the activity was determined based on the absorbance value of the molybdenum blue complexes which is equivalent to the amount of $\mathrm{N}$-acetyl-D-glucosamine produced from the enzymatic reaction of chitinase. The optimum temperature was determined from a graph of the relationship between temperature changes and enzyme activity.

The optimum incubation time was determined by the same procedure as the method used to determine the optimum $\mathrm{pH}$ and temperature, while the incubation time variations were $(30,60,90,120,150,180) \mathrm{min}$, at $45{ }^{\circ} \mathrm{C}$ and $\mathrm{pH}$ 7. Then the activity was determined based on the absorbance value of the molybdenum blue complexes which is equivalent to the amount of N-acetyl-Dglucosamine produced from the enzymatic reaction of chitinase. The optimum incubation time was determined from a graph of the relationship between time changes to enzyme activity.

\subsection{Effect of $\mathrm{Ca} 2+$ ions}

Addition of $\mathrm{Ca}^{2+}$ ions to increase chitinase activity was done by checking the chitinase reaction with variations in $\mathrm{Ca}^{2+}$ concentration, as follows: $(0 ; 0.2 ; 0.4 ; 0.6 ; 0.8) \%$. For each kind of treatment, $\mathrm{K}_{\mathrm{m}}$ and $\mathrm{V}_{\max }$ were measured. The enzyme activity and the $K_{m}$ and $V_{\max }$ values were determined employing the linear regression from the graph of the relationship between $\mathrm{V}^{-1}$ and $[\mathrm{S}]^{-1}$ (or called Lineweaver-Burk curve). Those enzyme reactions were done using the optimum parameter $(\mathrm{pH}$, temperature, incubation time) which was first tested.

\section{Results}

\subsection{Optimum Condition of Chitinase Activity}

Based on sequential trials on each reaction parameter, such as $\mathrm{pH}$, temperature, and incubation time, it is shown that chitinase from Vibrio sp. has optimum reaction condition at $\mathrm{pH} 7.5$ (Figure 1A), the temperature of $45{ }^{\circ} \mathrm{C}$ (Figure 1B), and $120 \mathrm{~min}$ incubation time (Figure 1C).
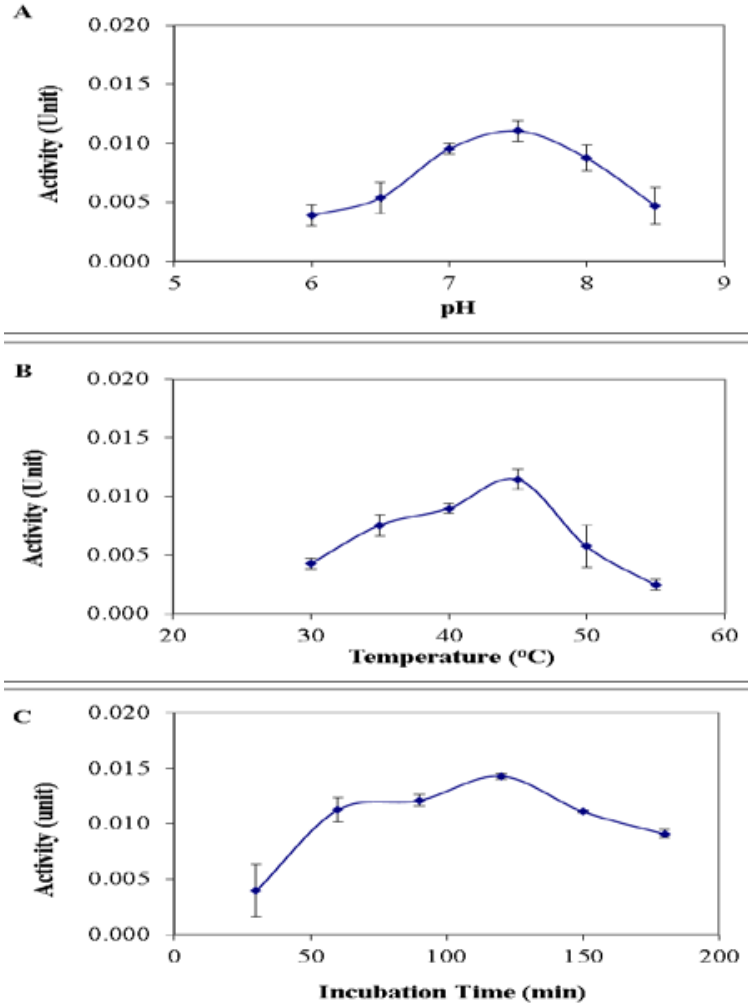

Figure 1. Optimum Condition Chitinase Activity at various $\mathrm{pH}$ (A), temperature (B), and incubation time (C). 


\subsection{Determination of $\mathrm{Km}$ and Vmax}

In this study, the determination of $\mathrm{K}_{\mathrm{m}}$ and $\mathrm{V}_{\max }$ of chitinase were carried out with variations in substrate (chitin) concentration as follows: $(1 ; 1.5 ; 2 ; 2.5 ; 3 ; 3.5) \%$ $(\mathrm{w} / \mathrm{v})$. The relationship of enzyme activity to substrate concentration is shown in Figure 2. It shows that the greater concentration of chitin, the greater the speed of the enzymatic reaction to a point where an increase in substrate concentration does not significantly increase the reaction speed.

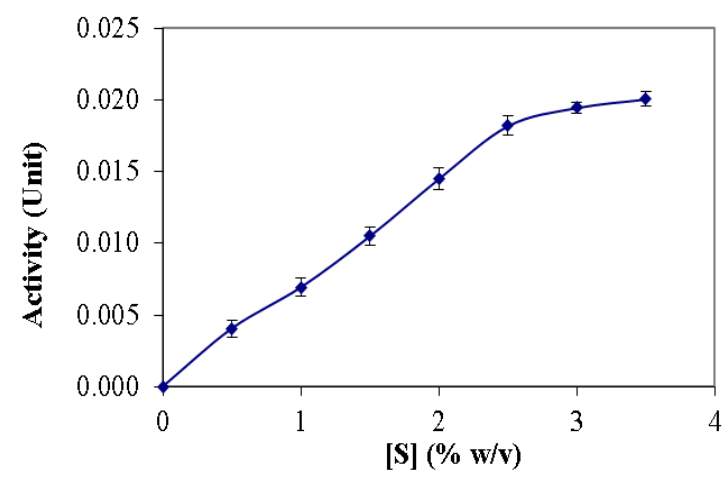

Figure 2. Relationship Curve of Chitinase Activity by Various Chitin Concentrations

Based on the Lineweaver-Burk curve shown in Figure 3 the values of $\mathrm{K}_{\mathrm{m}}$ and $\mathrm{V}_{\max }$ can be determined from the equation $\mathrm{Y}=\mathrm{aX}+\mathrm{b}$. The value of $\mathrm{V}_{\max }{ }^{-1}$ is 15.145 and $\mathrm{K}_{\mathrm{m}}$ $\mathrm{V}_{\max }{ }^{-1}$ is 117.84 , so the $\mathrm{V}_{\max }$ is $0.066 \mu \mathrm{mol} \mathrm{min}{ }^{-1}$ and $\mathrm{K}_{\mathrm{m}}$ is $7.781 \mu \mathrm{mol} \mathrm{mL} \mathrm{m}^{-1}$.

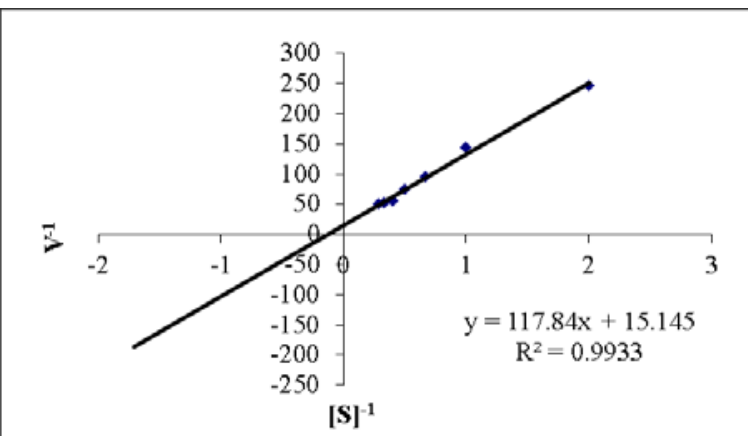

Figure 3. Lineweaver-Burk Curve of Chitinase Activity Isolated from Vibrio sp.

\subsection{The Role of Calcium Ions on Chitinase Enzyme Activity}

Figure 4. shows that $\mathrm{Ca}^{2+}$ increases enzyme activity until the addition of $0.4 \%(\mathrm{w} / \mathrm{v})$, whereas above $0.4 \%$, the enzyme activity starts to decline. The enzyme can be saturated with $\mathrm{Ca}^{2+}$ because the ability of the allosteric site to bind $\mathrm{Ca}^{2+}$ decreases. Thus, the addition of excess $\mathrm{Ca}^{2+}$ may cause denaturation on the enzyme which is characterized by decreased enzyme activity (Kumari et al., 2010).



Figure 4. Chitinase Activity with the Addition of $\mathrm{Ca}^{2+}$

The effect of chitinase activity in the presence of $\mathrm{Ca}^{2+}$ ions on various variations is shown in Figure 5. Changes in activity caused the price of $\mathrm{K}_{\mathrm{m}}$ and $\mathrm{V}_{\max }$ to change. The value of $\mathrm{K}_{\mathrm{m}}$ obtained is $6.723 \mu \mathrm{mol} \mathrm{mL} \mathrm{m}^{-1}$ and $\mathrm{V}_{\max }$ is $0.079 \mu \mathrm{mol} \mathrm{min}{ }^{-1}$ (Figure 6).



Figure 5. Chitinase Activity in the Various Concentration of the Substrate with $\mathrm{Ca}^{2+}$ Addition

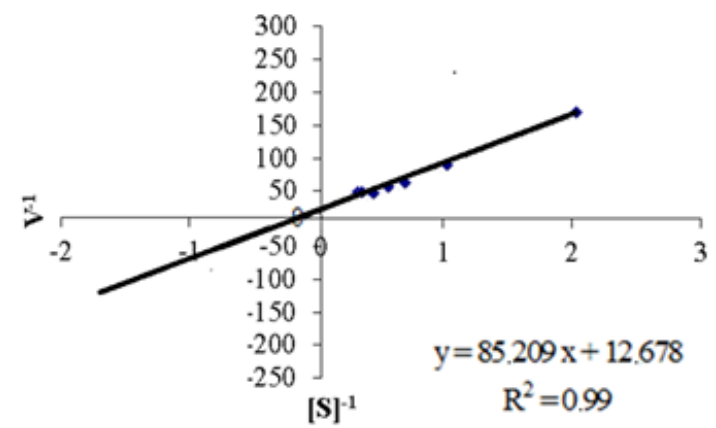

Figure 6. Lineweaver-Burk Curve Chitinase Activity by Addition of $\mathrm{Ca}^{2+}$

\section{Discussion}

The optimization results of chitinase activity (Figure 1) are concurrent with the previously reported study of He et al. (2020), which showed optimum chitinase activity at $\mathrm{pH}$ 5 to $\mathrm{pH} 7$ with incubation temperature at $45{ }^{\circ} \mathrm{C}$ to $50{ }^{\circ} \mathrm{C}$. However, it quite a different condition compared to other 
work of Nguyen and Nguyen (2020), which stated warm temperature $\left(30{ }^{\circ} \mathrm{C}\right.$ or $\left.35^{\circ} \mathrm{C}\right)$ and mildly alkaline $\mathrm{pH}(8.0)$ are the best conditions of chitinase from $V$. parahaemolyticus, one of the pathogenic species which infect shrimp.

One of the important things to know about the characteristics of an enzyme is the determination of $\mathrm{K}_{\mathrm{m}}$ and $\mathrm{V}_{\max }$. The Michaelis-Menten constant $\left(\mathrm{K}_{\mathrm{m}}\right)$ is a certain substrate concentration when the enzyme reaches half the maximum speed. Whereas Vmax is the maximum speed of an enzyme. To determine the value of $\mathrm{K}_{\mathrm{m}}$ and $\mathrm{V}_{\max }$, measurement of enzyme activity was done at various concentrations of substrate, under optimum conditions $(\mathrm{pH}$ 7.5, temperature $45{ }^{\circ} \mathrm{C}$, and $120 \mathrm{~min}$ incubation time). Thus, the $\mathrm{K}_{\mathrm{m}}$ indicates the amount of substrate needed to obtain high chitinase activity as indicated by $\mathrm{V}_{\max }$, which is the fastest enzyme reaction achieved at the optimum concentration (Nakamura et al., 2018). According to Robinson (2015), the speed of enzymatic reactions will increase with increasing substrate concentration until finally reaching a stationary point. After exceeding that point, although the substrate amount is increased, the increase of enzyme reaction speed is very small (almost constant), but will never reach the maximum condition. This condition limit is called the maximum speed $\left(\mathrm{V}_{\max }\right)$ where the enzyme becomes saturated by its substrate, as shown in Figure 2.

The Michaelis-Menten equation for precisely determining $\mathrm{K}_{\mathrm{m}}$ and $\mathrm{V}_{\max }$ is quite difficult. For this reason, the Michaelis-Menten equation is transformed into the Lineweaver-Burk equation. The Lineweaver-Burk equation is the opposite of the Michaelis-Menten equation which can determine $\mathrm{K}_{\mathrm{m}}$ and $\mathrm{V}_{\max }$ precisely, as shown in Figure 3. Thus the substrate concentration added was equal to the value of $\mathrm{K}_{\mathrm{m}}$. Whereas the $\mathrm{V}_{\max }$ value shows that the speed of the formation of the final product (N-acetyl-Dglucosamine) and the speed of returning to the enzyme chitinase must be the same as the speed of the breakdown of chitin that is equal to $0.066 \mu \mathrm{mol} \mathrm{min}{ }^{-1}$.

Calcium ions can form bridge complexes with enzymes and substrates according to their role in enzymatic reactions. $\mathrm{Ca}^{2+}$ can function as an enzyme inhibitor but can also be an enzyme activator. Enzymes that require $\mathrm{Ca}^{2+}$ as activators especially in extracellular enzymes (Bilecen and Yildiz, 2009; Garrison-Schilling et al., 2011). It plays an important role in modifying the structure needed for their catalytic activity. With the addition of substrate concentration, chitinase activity also increases with a fairly high increase in the concentration of $2.5 \%(\mathrm{w} / \mathrm{v})$. Calcium ion acts as an activator for enzymes that work to hydrolyze a macromolecule. The $\mathrm{Ca}^{2+}$ ions change the conformation and orientation of the active site of the enzyme, also increase the activeness of the enzyme to bind to the substrate to form an Enzyme-Substrate complex. The added $\mathrm{Ca}^{2+}$ influences chitinase activity because $\mathrm{Ca}^{2+}$ act as cofactors so that they can increase chitinase activity. The effect of $\mathrm{Ca}^{2+}$ on the chitinase isolated from Vibrio sp. is shown in Figure 4.

The presence of $\mathrm{Ca}^{2+}$ ions causes an increasing number of enzymes that bind to the substrate. This causes a greater level of substrate saturation as indicated by changes in the values of $\mathrm{K}_{\mathrm{m}}$ and $\mathrm{V}_{\max }$. Determination of $\mathrm{K}_{\mathrm{m}}$ and $\mathrm{V}_{\max }$ values was carried out by measuring chitinase activity with an optimum $\mathrm{Ca}^{2+}$ concentration of $0.4 \%$ in each variation of substrate concentration (Figure 5). The value of $\mathrm{K}_{\mathrm{m}}$ and $\mathrm{V}_{\max }$ (Figure 6) provides information that the substrate concentration needed to reach half of the maximum speed becomes smaller (13.5\% fewer) and the enzymatic reaction becomes faster (19.7\% faster) at the optimum concentration with the addition of $\mathrm{Ca}^{2+}$ ions. In the other words, additional $\mathrm{Ca}^{2+}$ up to $0.4 \%$ can provide benefits of larger chitinase activity and lesser required chitin.

Hydrolysis of chitin by chitinase with $\mathrm{Ca}^{2+}$ shows that the Calcium on the allosteric site (Asp-140) binds the substrate which can then change the active site conformation (Asp-142) to become active and bind to the substrate. When the conformation Asp-142 corresponds to the substrate and there is an interaction between those two, $\mathrm{Ca}^{2+}$ ions are released. The release of $\mathrm{Ca}^{2+}$ causes Asp-142 to rotate so that it is oriented closer to Glu-144 and hydrogen bonds occur. The interaction between Glu-144 and chitin causes the breakdown of glycosidic bonds and $\mathrm{N}$-acetyl-D-glucosamine is formed. The interaction between Asp-142 and the amine group chitin and chitin with water also causes the formation of N-acetyl-Dglucosamine (Paknisa, 2014).

The presence of $\mathrm{Ca}^{2+}$ ions causes an increasingly enzymatic reaction which is characterized by an increase in chitinase activity after adding $\mathrm{Ca}^{2+}$ ions. The increase in chitinase enzyme activity is still relatively smaller compared to the research of Park et al. (2000) after adding $\mathrm{Ca}^{2+}$ ions. This is allegedly due to the concentration of the addition of $\mathrm{Ca}^{2+}$ ions which are relatively small and the use of chitin substrate in the form of powder, so that chitinase work is less optimal than the use of chitin substrate in the form of colloids and the addition of greater $\mathrm{Ca}^{2+}$ ion concentrations. The presence of $\mathrm{Ca}^{2+}$ causes conformation changes that make enzymes bind easier with the substrate, thereby increasing the saturation of the enzyme to the substrate as indicated by the increase in $\mathrm{K}_{\mathrm{m}}$ and $\mathrm{V}_{\max }$ values.

\section{Conclusion}

The optimum reaction parameters for the chitinase isolated from Vibrio $s p$. are $\mathrm{pH} 7.5$, temperature $45^{\circ} \mathrm{C}$, and 120 min incubation time. The chitinase activity increases until the addition of $\mathrm{Ca}^{2+} 0.4 \%$ and decreases with an increasing concentration of $\mathrm{Ca}^{2+}$ above $0.4 \%$. The value of $\mathrm{K}_{\mathrm{m}}$ and $\mathrm{V}_{\text {max }}$ before adding $\mathrm{Ca}^{2+}$ was $7.781 \mu \mathrm{mol} \mathrm{mL} \mathrm{m}^{-1}$ and $0.066 \mu \mathrm{mol} \mathrm{min}^{-1}$, respectively. After adding $\mathrm{Ca}^{2+}$, the




$\mu \mathrm{mol} \min ^{-1}$. In conclusion, chitinase kinetic parameters with the addition of $\mathrm{Ca}^{2+}$ affects $\mathrm{K}_{\mathrm{m}}(13.5 \%$ fewer substrate) and $\mathrm{V}_{\max }$ (19.7 \% faster), which means its reaction efficiency is improved.

\section{Competing interest statement}

The authors have declared that no competing interest exists in the manuscript.

\section{Acknowledgments}

Appreciation was sincerely conveyed to the Head of Laboratory for Fish Health and Environment Assessment, Muntilan, Central Java, Indonesia who has supported the place to carry out the research. We also thank the Head of the Laboratory from all related affiliations for providing the means for the implementation of this research.

\section{Funding disclosure}

The researchers would like to thank several parties who helped in this research, namely the UMM Rector and staff who have helped fund this research; Director of Directorate of Research and Community Service (DPPM) of the University of Muhammadiyah Malang (UMM), and staff (contract Number. 1322/SK-BAA/XII/2016), who facilitated the implementation of this research.

\section{References}

Adrangi S and Faramarzi MA. 2013. From bacteria to human: A journey into the world of chitinases. Biotechnol Adv, 31(8): 17861795.

Atalla SM, Gamal NG and Awad HM. 2020. Chitinase of marine Penicillium chrysogenum MH745129: isolation, identification, production and characterization as controller for citrus fruits postharvest pathogens. Jordan J Biol Sci, 13(1): 19-28.

Awad HM, El-Enshasy HA, Hanapi SZ, Hamed ER and Rosidi B. 2014. A new chitinase-producer strain Streptomyces glauciniger WICC-A03: isolation and identification as a biocontrol agent for plants phytopathogenic fungi. Nat Prod Res, 28(24): 2273-2277.

Bilecen $\mathrm{K}$ and Yildiz FH. 2009. Identification of a calcium-controlled negative regulatory system affecting Vibrio cholerae biofilm formation. Environ Microbiol, 11(8): 20152029Felix F, Nugroho TT, Silalahi S and Octavia Y. 2011. Screening of Indonesian original bacteria Vibrio sp. as a cause of shrimp diseases based on 16s ribosomal DNA-technique. Jurnal Ilmu dan Teknologi Kelautan Tropis, 3(2): 85-99.

Garrison-Schilling KL, Grau BL, McCarter KS, Olivier BJ, Comeaux NE and Pettis GS. 2011. Calcium promotes exopolysaccharide phase variation and biofilm formation of the resulting phase variants in the human pathogen Vibrio vulnificus. Environ Microbiol, 13(3): 643-654.

Hamed ER, Awad HM, Ghazi EA, El-Gamal NG and Shehata HS. 2015. Trichoderma asperellum isolated from salinity soil using rice straw waste as biocontrol agent for cowpea plant pathogens. $J$ Appl Pharm Sci, 5(2): 091-098.

Harini N and Indranila TH. 2006. Purification of crude extract of kinitase enzyme from Vibrio cumpbelli by multilevel precipitation method with ammonium sulfate. Prosiding Seminar Nasional Tahunan III Hasil Penelitian Perikanan dan Kelautan. Balitbang Kelautan dan Perikanan. Yogyakarta. pp. 267-276.

He X, Yu M, Wu Y, Ran L, Liu W and Zhang XH. 2020. Two highly similar chitinases from marine Vibrio species have different enzymatic properties. Mar Drugs, 18(139): 1-14.

Jahromi ST and Barzkar N. 2018. Marine bacterial chitinase as sources of energy, eco-friendly agent, and industrial biocatalyst. Int J Biol Macromol, 120: 2147-2154.

Kharisma A and Manan A. 2012. The Abundance of Vibrio sp. bacteria on enlargement water of Whiteleg shrimp (Litopenaeus vannamei) as the early detection of Vibriosis. Jurnal Ilmiah Perikanan dan Kelautan, 4(2): 129-134.

Krolicka M, Hinz SW, Koetsier MJ, Eggink G, van den Broek LA and Boeriu CG. 2018. $\beta$-N-Acetylglucosaminidase Mth NAG from Myceliophthora thermophila C1, a thermostable enzyme for production of N-acetylglucosamine from chitin. Appl Microbiol Biotechnol, 102(17): 7441-7454.

Kumari A, Rosenkranz T, Kayastha AM and Fitter J. 2010. The effect of calcium binding on the unfolding barrier: A kinetic study on homologous $\alpha$-amylases. Biophys Chem, 151(1-2): 54-60.

Kusmarwati A, Hermana I, Yennie Y and Wibowo S. 2017. Presence of potentially human pathogenic Vibrio parahaemolyticus of fresh shrimp in ponds of the northern coast of Java. Jurnal Pascapanen dan Bioteknologi Kelautan dan Perikanan, 11(1): 4154.

Nguyen PN and Nguyen TT. 2020. Effects of pH, temperature and oxygen-limited condition on the virulence of Vibrio parahaemolyticus. Sci Tech Dev J, 23(3): 569-575.

Paknisa S. 2014. Studies on chitinolytic enzymes from Vibrio Harveyi: Transglycosylation reaction and inhibition kinetics of sodium salts. Doctoral dissertation, School of Biochemistry Institute of Science, Suranaree University of Technology, Thailand.

Park SH, Lee JH and Lee HK. 2000. Purification and characterization of chitinase from a marine bacterium, Vibrio $s p$. 98CJ11027. J Microbiol, 38(4): 224-229.

Rathore AS and Gupta RD. 2015. Chitinases from bacteria to human: properties, applications, and future perspectives. Enzyme Res, 791907: 1-8. Sadik MW, Zohair MM, El-Beih AA, Hamed ER and Sedik MZ. 2021. Utilization of Agro-industrial wastes as carbon source in solidstate fermentation processes for the production of value-added byproducts. Jordan J Biol Sci, 14(1): 157-161.

Shalaby HM, Abo-Sdera SA, Easa SM and Ismail AM. 2019. Biosynthesis of biologically active chitinase utilizing some Egyptian chitinaceous wastes and the properties of the synthesized enzyme. Egypt Pharm J, 18(4): 320-331.

Taqwa FH, Sasanti AD, Haramain K, Kusrini E and Gaffar AK. 2014. Addition of calcium to swamp water as a diluent for salinity media for post-larvae maintenance of giant prawns on survival, 
osmotic work rate, and oxygen consumption. Jurnal Riset Akuakultur, 9(2): 229-236.

Utami W. 2016. Effect of salinity on Vibrio harveyi infection in Whiteleg Shrimp (Litopenaeus vannamei)]. J Aqua Manag Technol, 5(1): 82-90.

Van den Broek LAM, Knoop RJI, Kappen FHJ and Boeriu CG. 2015. Chitosan films and blends for packaging material. Carbohydr Polym, 116: 237-242.

Veliz EA, Martínez-Hidalgo P and Hirsch AM. 2017. Chitinaseproducing bacteria and their role in biocontrol. AIMS Microbiol, 3(3): 689-705.
Yang S, Fu X, Yan Q, Guo Y, Liu Z and Jiang Z. 2016. Cloning, expression, purification and application of a novel chitinase from a thermophilic marine bacterium Paenibacillus barengoltzii. Food Chem, 192: 1041-1048.

Zafran Z, Roza D and Koesharyani I. 2017. Resistance of Vibrio isolated from infected Penaeus monodon to antibiotics. Jurnal Penelitian Perikanan Indonesia, 3(1): 11-15.

Zarkasi KZ, Shukri AA, Nazari TF, Abdullah AA and Daud F. 2019. Molecular characterization of microbial community diversity associated with Blood Cockles (Anadara granosa) in Blood Cockle Farms. Jordan J Biol Sci, 12(3): 339-344. 